\title{
Economic Impact of Improved Cattle Feeding Practice on Performance Dairy Farms and Household Welfare in Northern Ethiopia
}

\section{Muuz Hadush ${ }^{1}$}

\begin{abstract}
In this paper, efforts were made to estimate the impact of stall feeding (SF) technology on households' milk production and consumption, market participation as well as land conservation in rural Northern Ethiopia using data obtained from a survey of 518 rural farmers. Using endogenous switching regression models, we estimate different outcome indicators for both adopters from adopting SF (ATT), and non-adopters had they adopted (ATU). The values of ATT and ATU show that SF adoption increased milk production, consumption expenditure, number of plantation and of physical construction, propensity of participating in animal market sale and growing trees in their plots.
\end{abstract}

Keywords: Milk production and consumption; Animal market participation land investment; Endogenous switching regression, Ethiopia.

\footnotetext{
${ }^{1}$ Norwegian University of Life Sciences (NMBU), School of Economics and Business, Box 5003, 1432 Ås, Norway.

Email: muuz.hadush.gebremichael@nmbu.no
} 


\section{Introduction}

Agriculture is an important motor for realizing economic development in sub-Saharan Africa (SSA) where agriculture accounts for about 43 per cent of the Gross Domestic Product (GDP) and over 60 per cent of exports (Odame et al., 2013). Nearly about 90 per cent of the poor depend on agriculture to lift them out of poverty. However, unlike other regions of the world, the region have continued to experience low agricultural productivity with its share of 3.9 per cent to world food production in the last decade (Odame et al., 2013). A large proportion of the rural households in developing countries own livestock, which are financially valuable and play significant social and economic roles in rural farms (World Bank, 2008; Herrero et al., 2013). Livestock contribute to the livelihoods of at least 70 per cent of Eastern Africa's rural farmers in terms of income and diet (Cecchi et al., 2010).

In Ethiopia, dairy sector plays an important role in the agricultural sector (Tegegne et al., 2013). Livestock contributes about 12-16 per cent of the total GDP, and 40 per cent of total agricultural GDP excluding the values of draught power, transport and manure, and contributes to the livelihoods of about 60-70 per cent of the population (Halderman, 2004). Milk and milk products play a very important role in feeding the rural and urban people. It also provides 14 million tons of manure annually, which mainly used for fuel. The value of animal draught power input into arable production is about a quarter of the value of annual crop production (FAO, 2005; Behnke \& Metaferia, 2011). However, the performance of livestock sector has been poor compared to the other parts of the world due to inadequate nutritious feed and poor feeding practices, shrinking of natural pasture lands, animal infection and weather fluctuation (IFAD, 2007; FAO, 2009; Odame et al., 2013) combined with the predominance of local, low-yielding breeds, the inadequate availability of water resources for drinking and the high rates of livestock mortality (Negassa \& Jabbar, 2008).

In spite of its huge potential, production per animal is extremely low in Ethiopia (CSA, 2008; MoA, 2012). The average milk production is only 1.54 litres per cow per day. The current per capita consumption of milk and meat is 16 litres and $13.9 \mathrm{~kg} /$ year, respectively; being lower than the African and the world per capita averages, which are $27 \mathrm{~kg} / \mathrm{year}$ and $100 \mathrm{~kg} / \mathrm{year}$, respectively (FAO, 2009). As a result, Ethiopia is classified as having the lowest per capita consumption of meat and milk, even among neighbouring countries like Kenya. Land degradation resulting from free grazing lands and deforestation reduces the contribution from livestock and pose a threat to food security in the region (Ilyin, 2011). Recognizing this, improved agricultural technologies are widely considered as the key means of addressing low livestock productivity throughout the region (Diao \& Pratt, 2007). The expansion of improved cattle feeding has been suggested by policy makers with the objectives of (1) increasing cattle and fodder productivity; (2) halting land degradation, and (3) generating income (Lenaerts, 2013). 
For instance, stall-feeding (SF) or zero Grazing (ZG) has been widely recommended and was practiced across sub-Saharan Africa while its pace of intensification was slower-than-anticipated (Lenaerts, 2013; De Cao et al., 2013; Bishu, 2014). The practice of stall feeding along with the improved cows is being promoted in Ethiopia in different phases as potential options for alleviating animal feed shortage problems and increasing livestock productivity (Benin et al., 2006; De Cao et al., 2013; Lenaerts, 2013; Bishu, 2014; Klitzing et al., 2014). The introduction of stall-feeding as the system under which cattle are kept permanently are feed fodder crops, crop residues via 'cut-and-carry system' entails the establishment of garden pastures, demarcation of the homestead for herding, breeding and fodder trees under intensive feed gardens for forage production.

Earlier studies using descriptive statistics in the region indicated that SF /ZG has several benefits over extensive grazing systems: SF offers a regular income throughout the year as compared to cash crops (Klitzing et al., 2014). It is also linked to a better utilization of fodder, increased milk output, better manure management, intensive land use, and low risk of infection by tickborne diseases, and protection of animals against theft (Bishu, 2014). Besides, Garcia et al., (2008) using qualitative method found that SF in Uganda was economically and ecologically sustainable. Baltenweck et al., (2007) in Tanzania and Staal et al., (2003) from Kenya proved that ZG was more profitable than free grazing using simple budget analysis method. De Cao et al., (2013) revealed that $\mathrm{ZG}$ is a potentially useful practice against low productivity and limited feed availability in Ethiopia. Although SF is believed to be profitable, its pace of coverage has been recorded to be slow and low in the region (Nedessa et al., 2005; FAO, 2007; Lenaerts, 2013; Bishu, 2014; Hadush \& Hagos, 2018).

The relative advantage that a new practice offers is one possible reason for speeding or slowing the adoption of a new practice (Ghadim et al., 2005). Based on Cary et al., (2001), the expected profit is a decisive factor in adoption decisions. Ghadim et al., (2005) revealed that the short-term profitability of new legume crops significantly influenced their adoption. D'Emden et al., (2006) found that the adoption of conservation tillage in Australia was influenced by its cost. The economic and ecological benefits of SF are neither properly documented nor proper evaluation was designed. The objective of this paper was, therefore, to estimate adoption of SF and evaluate the impact of adoption on rural household's welfare in rural Ethiopia using Endogenous Regression model (Lokshin \& Sajaia, 2004).The paper intends to address research question of what is the economic impact of SF. To what extent adopters would be worse off if they had not adopted and how much benefits non-adopter would gain had they adopted?

The uses of Endogenous Regression model (ERM) allow us to hypothesize that adopters would be worse off than non-participants if they decided not to adopt and non-participants would benefit more than participants 
if they were to participate that is we anticipate that the predicted impact for adopters will decline from real adoption to hypothetical adoption but will increase from real non-adoption to hypothetical adoption for non-adopters. This paper is distinguished from past related studies in three ways: First, we are perhaps the first to show how stall feeding users compared to non-users are benefitting using proper evaluation design than prior survey studies which totally neglected the selectivity effects and endogeneity problem. A second is an approach which provides not only a joint estimation of adoption and its impact but also estimates of conditional and unconditional expectation. Third, stall feeding is a new practice in the country whose adoption is recorded to be slow, may be resulted from non-realization of its positive impact. Being able to estimate with precision its impact would influence the types of policies that can be embarked upon the expansion of its coverage.

\section{Literature Review}

Livestock is a primary livelihood source for many low-income rural farmers particularly Sub-Saharan Africa (Grassi et al., 2015). In line to this, Yilma et al., (2011) indicated that livestock production in Ethiopia contributes up to 80 per cent of farmers' income, about 20 per cent of agricultural GDP, full year employment and share of 16 per cent to export. In spite of large cattle population size, the contribution of livestock production to agriculture is below expected level and is further deteriorating (Gebremedhin et al., 2004; Ilyin, 2011). The average daily milk production was only 1.69 litres with average lactation length of about 180 days and mean annual milk yield per cow of 305 litres. The per capita milk consumption per annum has decreased from 26 litres in 1980 to 22 litres in 1993, 19 litres in 2000 and 16 litres in 2009 (Yilma et al., 2011). A study conducted by Klitzing et al., (2014) in the highlands of Ethiopia showed that the performance of the sector is challenged primarily by a low quality and quantity of feed resources and seasonal fluctuations in feed resources.

Similarly to many other environmentally vulnerable countries, Ethiopia has faced rampant land degradation in the form of immense of gully and soil erosion caused by overgrazing and deforestation (Gessesse et al., 2016; Teshome et al., 2016). In response to extensive degradation of the resource base, different land management measures such as stone terraces, soil bunds and agroforestry practices on cultivated fields, as well as area closure have been introduced (Frankl et al., 2016) in the country. Ewnetu and Bliss (2010) and Teshome et al., (2016), mentioned that among others, demographic characteristics, farming practices, agro-ecological conditions, access to roads and markets, and land-use policies, property rights and level of extension services are some of the critical factors affecting management investment decisions in Ethiopia. In view of this, the extent to which the practice of SF could affect planting decision is examined in this study.

As mentioned above, throughout Sub-Saharan Africa, the introduction of improved feeding has been seen by policymakers as key objectives of (1) 
increasing livestock productivity; (2) curtailing land scarcity and land degradation, and (3) generating income. In line to this, stall-feeding (zero grazing), rotational grazing and tethering where animals are fed dry hay, straw, cactus and other extra nutritional fodders under a sheltered woody tent or tree shelter have been widely recommended across the region and was practiced in the highlands of Kenya, Tanzania and Ethiopia (Gebremedhin et al., 2009; Lenaerts, 2013; Bishu, 2014; Klitzing et al., 2014) although its expansion was slower-than-anticipated.

Sserunkuuma (2005) in his study of the adoption of land management technologies in Uganda found that low adoption of improved technology is associated with low profitability. Farmers tend only to use technologies that they consider profitable despite all other non-monetary factors that could determine technology adoption decision (Kabirizi, 2006).

The practice of SF in Uganda was found to be economically and ecologically sustainable (Garcia et al., 2008). Zero grazing in Tanzania was more economically and environmentally viable where improved cows under this practice produce 1.500 litres of milk per lactation of 1.5 years at a cost of 1.000 hours annually for collecting fodder and water (Holtland, 2007) but Meul et al., (2012) in Australia found that zero-grazing performed significantly worse from an ecological and economic point of view. A recent study by Klitzing et al., (2014) in Ethiopia revealed that fodder productivity from SF schemes are higher than from Free Grazing (FG) schemes, leading to overall livestock productivity and higher welfare gain. A survey study conducted by Nyssen et al., (2007) in the Tigrai also show that modern grazing practices had ecological and economic benefits. Likewise, Hadush and Hagos (2018) using IV 2SLS found that ZG increases milk production and reduces probability of newly born calf death in Tigrai.

Nalunkuuma et al., (2013) indicated that adoption of ZG had a positive impact on farmers' breed cow possession in Kenya. De Cao et al., (2013) revealed that $Z G$ was a useful practice to improve cattle productivity and feed availability by reducing free grazing months in Ethiopia. Another result confirmed that almost 80 per cent of the farmers that adopted improved breeds also adopted stall feeding (Benin et al., 2006). The finding from Turinawe et al., (2011) revealed that farmers using improved forage technology had significantly higher gross profit and number of breed cows than those using local feeding methods in Uganda. Results from Wambugu et al., (2011) indicated that, on average, the value of milk in the ZG system was Ksh. 6,091, compared to Ksh. 5,189 in FG systems. Lactation length under SF is 450 days versus 200 days for free grazing. Pre-weaning calf mortality is about 10 per cent per annum in ZG than 25 per cent in FG. However, about 730 hours of labour per cow per year is required for SF than 330 hours for FG and hence households practicing ZG incurred higher monthly variable costs per lactating cow compared to that for non-ZG. 
An empirical study of Hadush (2018) in Tigrai showed that village grazing land, village exclosure area, labour, cattle stock, farm size, animal shock exposure, number of breed cows, access to information and village exposure to stall feeding are key factors of SF adoption. SF is also supposed to minimize risks mainly associated with cattle contact and disease prevalence in FG (Bishu, 2014). While agronomic benefits of this practice are well documented, economic benefits, however, remained unexplored (Gebregziabher \& Gebrehiwot, 2011; Hadush, 2018; Hadush \& Hagos, 2018) in the study region.

\section{Theoretical Model}

In most cases, smallholder farmers make an important decision when they choose to participate in a new intervention. In order to estimate the effect of stall feeding on milk production, consumption and market participation, the farm household model in which household maximize utility subject to income, production, and time constraints (Singh et al., 1986) was adopted as a framework. The choice of this model is based on its merit of integrating the production, consumption and work decision-making processes of the farm household in a single framework. This paper mainly draws from FernandezCornejo et al., (2005) who expanded the model of Huffman (1991) to include technology adoption decisions.

Farm households are assumed to derive utility $(U)$ from purchased consumption goods $(G)$ and a vector of members' leisure and non-economic activities at home $(L)$, and the level of utility obtained from $G$ and $L$ is influenced by exogenous factors such as human capital $(K)$ and other household characteristics $(C)$. Consulting the work of Fernandez-Cornejo et al., (2005), the utility is denoted by:

$$
\operatorname{Max} U=U(G, L ; K, C)
$$

Where $\mathrm{U}$ is assumed to have the usual regularity properties of a utility function, such as twice differentiability, quasi-concavity, and increasing in $G, L ; K, C$. The objective of the farm household is to maximize utility from the consumption of goods and leisure subject to the farm production, income, and time constraints:

Time constraint: $\quad T=\mathrm{F}(S F)+M+L, M \geq 0$

Production constraint: $Q=Q[X(S F), \mathrm{F}(S F), K, S F, R], S F \geq 0$

Income constraint: $\quad P_{g} \mathrm{G}=P_{q} Q-W_{x} X^{\prime}+W M^{\prime}+A$

The production technology (3) is assumed to have all the regularity conditions, such as twice differentiable, increasing in inputs, etc. The total household's time endowment $(T)$ is devoted to leisure $(L)$; working on the 
farm $(F)$; and off-farm work $(M)$, while the farm output level $(Q)$ depends on the quantity of farm inputs $(X)$ such as land, capital, breed cows, feed etc. and the practice of new feeding $(S F)$, where $S F$ is considered to be labour and feed-saving technology adoption decision, resulting in some free time and money for other activities, F, K, and a vector of exogenous variables that shifts the production function $(R)$. The adoption of labour-saving technology $S F$ reduces the labour requirement in cattle farm production. Thus, its adoption should be incorporated into the production technology implicitly, not as a shifter of the production function. The adoption of $S F$, is further affected by households' animal shock exposure $(S)$, private social capital $(N)$, household $\operatorname{assets}(E), \mathrm{K}$ and $\mathrm{C}$. Thus:

$$
S F=(S, N, E, K, C, R)
$$

Equation (4) displays the budget constraint on household income where $P_{g} \mathrm{G}$ is the income available for purchase of consumer goods at a price $P_{g}$, and it depends on the output price $\left(P_{q}\right)$ and quantity $(Q)$ of farm output; vector input prices $\left(W_{x}\right)$ of quantity $(X)$ of farm inputs; off-farm wages $(W)$ and the amount of time spent working off-farm $(M)$ as well as exogenous household income such as private assistance and safety net support $(A)$. Substituting equation 3 into equation 4 produces a farm technologyconstrained measure of household income:

$$
P_{g} \mathrm{G}=P_{q} Q[X(S F), \mathrm{F}(S F), K, S F, R]-W_{x} X(S F)+W M^{\prime}+A
$$

Maximizing Lagrangian expression $(\mathscr{L})$ over $(G, L)$ but minimizing it over $(\lambda, \eta)$ yields the Kuhn-Tucker first order conditions:

$$
\begin{aligned}
& \mathscr{L}=U(G, L ; K, C)+\lambda\left\{P_{q} Q[X(S F), \mathrm{F}(S F), K, S F, R]-W_{x} X(S F)+W M^{\prime}+\right. \\
& \left.A-P_{g} \mathrm{G}\right\}+\eta[T-\mathrm{F}(S F)-M-L]
\end{aligned}
$$

where $\lambda$ and $\eta$ represent the Lagrange multipliers for the marginal utility of income and time, respectively. The Kuhn-Tucker first-order conditions are:

$$
\begin{array}{ll}
\frac{\partial \mathcal{L}}{\partial G}= & U_{G}-\lambda P_{g}=0, \\
\frac{\partial \mathcal{L}}{\partial L}= & U_{L}-\eta=0, \\
\frac{\partial \mathcal{L}}{\partial S F}= & \lambda\left[P_{q}\left\{\frac{\partial Q}{\partial X} * \frac{\partial X}{\partial S F}+\frac{\partial Q}{\partial \mathrm{F}} * \frac{\partial \mathrm{F}}{\partial S F}\right\}\right]-W_{x} \frac{\partial X}{\partial S F}-\eta \frac{\partial \mathrm{F}}{\partial S F}=0 \\
\frac{\partial \mathcal{L}}{\partial X}= & \lambda\left[P_{q} \frac{\partial Q}{\partial X}-W_{x}\right]=0, \\
\frac{\partial \mathcal{L}}{\partial F}= & \lambda P_{q} \frac{\partial Q}{\partial \mathrm{F}}-\eta=0 \\
\frac{\partial \mathcal{L}}{\partial M}= & \lambda W-\eta=0 \\
\frac{\partial \mathcal{L}}{\partial \lambda}= & P_{q} Q[X(S F), \mathrm{F}(S F), K, S F, R]-W_{x} X(S F)+W M^{\prime}+A-P_{g} \mathrm{G}=0 \\
\frac{\partial \mathcal{L}}{\partial \eta}= & T-\mathrm{F}(S F)-M-L=0
\end{array}
$$


Based on the Kuhn-Tucker condition solution (Fernandez-Cornejo et al., 2005), solving the model, we could find the following input demand functions:

$$
X^{*}=\left(W_{x}, P_{q}, S F, W, \mathrm{~K}, \mathrm{C}, \mathrm{T}\right)
$$

Thus, the reduced-form expression of the optimal level of household milk income $\left(Y^{*}\right)$ can be obtained by substituting the optimal input demand functions into the technology constraint (3) as follows;

$$
Y^{*}=\left(W_{x}, P_{q}, S F, W, \mathrm{~K}, \mathrm{C}, \mathrm{R}, \mathrm{T}\right)
$$

Likewise, solving jointly equations (7.1), (7.2), (7.7) and (9), household demand for consumption goods $(G)$ can be expressed as:

$$
G=\left(S F, P_{g}, P_{q}, \mathrm{Y}^{*}, A, \mathrm{~K}, \mathrm{C}, \mathrm{T}\right)
$$

Thus, the reduced forms of $\mathrm{Y}^{*}$ and $G$ are affected by a set of explanatory variables, including $S F$ where this paper is mainly intended to estimate the effect of $S F$ on household milk income, household consumption of milk and milk products, market participation and land conservation.

\section{Description of the Study Area and Data}

The study is conducted in Tigrai region, the northern part of Ethiopia by randomly selecting 632 sample households. This study used a crosssectional data from Tigrai Rural Household Survey (TRHS) ${ }^{2}$ data collected in 2015. The available panel dataset provides comprehensive household and plot level data. The primary data used in this paper is adapted from the last, 2014/2015, household survey. Table 1 presents the basic socio-economic characteristics of 518 livestock owner-farmers drawn from a total of 632 sample farmers. The estimation of SF's impact on milk production and consumption reduces our sample size from 632 sample farmers to 518, those who only have cattle and harvested milk during the study year.

The outcome variables in this paper include households' milk production; animal product (milk, butter, cheese, yogurt, and dung) consumption, animal sale market participation, lactation length during the survey production year. As noted earlier, adopters are classified as farmers those who practice stall feeding at least for one animal in the full year (FSF) or in an at least single season (SSF) during the survey period, while nonadopters are farmers that follow traditional free grazing. The result showed that

2 TRHS includes a panel of five rounds conducted in 1997/98, 2000/01, 2002/03, 2005/06 and 2014/2015 where the author is involved only in the last round. 
the percentage of full adopters and non-adopters in the full year round is reported to be 36.1 per cent and 63.9 per cent respectively. However, farmers practicing SF at least in one season are 55.6 per cent, whereas those nonadopters are 44.4 per cent in the study area. Table 1 report summary statistics for the selected outcome indicators and key household characteristics. Adopters of SF are seemingly better off than non-adopters in many aspects.

The average milk yield of a dairy cow in the study area is estimated to be 1.69 for adopters and for non-adopters 1.46 litres per cow per day, which is much lower than in neighbouring Kenya (Wambugu et al., 2011). Moreover, adopters are more likely to be involved in animal and animal product markets than non-adopters, 54 per cent of the adopters have participated in the market compared to that of non-adopters (51 per cent). Adopters have a significantly higher annual milk and meat consumption expenditure, lactation period. These all indicators point to the fact that adopters are likely to be benefited more than non-adopters. The same statistical analysis result shows that adopting farmers have lower herd size (3.9 TLU) than non-adopters (4.1TLU) but have a higher number of milking cows (72 per cent) than 64 per cent for non-adopters.

Table1: Description and summary statistics for SF adoption decision

\begin{tabular}{|c|c|c|c|}
\hline Variable description & $\begin{array}{l}\text { Non-adopters } \\
\text { Mean }\end{array}$ & $\begin{array}{l}\text { Adopters } \\
\text { Mean }\end{array}$ & $\begin{array}{l}\mathrm{T}=\text { test } \\
\mathrm{P} \text {-value }\end{array}$ \\
\hline $\begin{array}{l}\text { Network( assistance from } \\
\text { relatives/friends ,ETB ) }\end{array}$ & 1336.3 & 1508.8 & 0.7023 \\
\hline Gender ( $1=$ if household head is male) & 0.7643 & 0.8395 & 0.2973 \\
\hline $\begin{array}{l}\text { Education ( } 1=\text { if household head is } \\
\text { literate) }\end{array}$ & 3716 & 0.4545 & 0.0646 \\
\hline $\begin{array}{l}\text { Credit ( } 1=\text { if household had access to } \\
\text { credit in 2014/2015) }\end{array}$ & 0.2416 & 0.2834 & 0.2973 \\
\hline $\begin{array}{l}\text { Cart ( } 1=\text { if household head own cart } \\
\text { tool) }\end{array}$ & 0.0906 & 0.1497 & 0.0406 \\
\hline $\begin{array}{l}\text { Improved ( } 1=\text { if household head had } \\
\text { breed cows) }\end{array}$ & 0.0120 & 0.1122 & 0.0000 \\
\hline $\begin{array}{l}\text { Information ( } 1=\text { if household own } \\
\text { Radio, TV and Mobile) }\end{array}$ & 0.1359 & 0.3048 & 0.0000 \\
\hline $\begin{array}{l}\text { Fodder shed (1=if household head own } \\
\text { fodder shed) }\end{array}$ & 0.0060 & 0.0320 & 0.0209 \\
\hline $\begin{array}{l}\text { Location }(1=\text { if household lives above } \\
2000 \text { m.a.s.l) }\end{array}$ & 0.0664 & 0.0588 & 0.7329 \\
\hline $\begin{array}{l}\text { Distance to nearest road (in walking } \\
\text { minute) }\end{array}$ & 34.38 & 28.27 & 0.0363 \\
\hline Household head age (years) & 57.66 & 57.26 & 028.27 \\
\hline Family labour (Hours) & 82.31 & 91.19 & 0.1619 \\
\hline Farm income (Ethiopian currency, & 6689.5 & 5319.7 & 0.3284 \\
\hline
\end{tabular}


Table 1 contd...: Description and summary statistics for SF adoption decision

\begin{tabular}{|c|c|c|c|}
\hline Variable description & $\begin{array}{l}\text { Non-adopters } \\
\text { mean }\end{array}$ & $\begin{array}{l}\text { Adopters } \\
\text { Mean }\end{array}$ & $\begin{array}{l}\mathrm{T}=\text { test } \\
\mathrm{P} \text {-value }\end{array}$ \\
\hline $\begin{array}{l}\text { Grazing area to household ratio } \\
\text { (Ha/number) }\end{array}$ & 0.0018 & 0.0012 & 0.0000 \\
\hline $\begin{array}{l}\text { Distance to free grazing (walking } \\
\text { minute) }\end{array}$ & 54.85 & 62.77 & 0.0310 \\
\hline Forage expense (ETB) & 143.59 & 112.2 & 0.1660 \\
\hline $\begin{array}{l}\text { Total plots owned by the household } \\
\text { (number) }\end{array}$ & 3.480 & 3.887 & 0.0236 \\
\hline Village Experience of SF (year) & 3.214 & 4.331 & 0.0000 \\
\hline Distance to market (walking minuets) & 79.14 & 78.77 & 0.9407 \\
\hline Off farm income (ETB) & 3638.1 & 6678.8 & 0.2363 \\
\hline Value of all farm tools (ETB) & 549.89 & 797.01 & 0.0625 \\
\hline Farm size(ha) & 1.173 & 1.132 & 0.6835 \\
\hline Distance to nursery (Walking minutes) & 59.85 & 58.58 & 0.7863 \\
\hline Feed supplementary expense (ETB) & 144.07 & 112.70 & 0.0071 \\
\hline Total family size (number) & 5.65 & 6.25 & 0.0071 \\
\hline Access to animal shed $(\mathrm{Yes}=1)$ & 0.0574 & 0.1122 & 0.0246 \\
\hline Veterinary expense (ETB) & 118.2 & 103.88 & 0.2018 \\
\hline \multicolumn{4}{|l|}{ Dependent variables in the first equation } \\
\hline Total herd size (TLU) & 4.078 & 3.953 & 0.6520 \\
\hline $\begin{array}{l}\text { Total milk production per household } \\
\text { (litre/day) }\end{array}$ & 2.134 & 2.465 & 0.1376 \\
\hline Milk yield (litres per cow per day) & 1.459 & 1.699 & 0.0033 \\
\hline Animal shock experience (Yes=1) & 0.157 & 0.283 & 0.0006 \\
\hline Hired labour $($ Yes $=1)$ & 0.414 & 0.342 & 0.1084 \\
\hline Lactation period (months) & 7.609 & 8.459 & 0.0000 \\
\hline $\begin{array}{l}\text { Own milk and milk product } \\
\text { consumption expenditure (ETB) }\end{array}$ & 1549 & 1856 & 0.2101 \\
\hline $\begin{array}{l}\text { Animal and animal product market } \\
\text { participation }(\mathrm{Yes}=1)\end{array}$ & 0.514 & 0.540 & 0.5626 \\
\hline $\begin{array}{l}\text { Length of biophysical construction } \\
\text { (metre) }\end{array}$ & 189.35 & 233.8 & 0.4816 \\
\hline Growing trees in plots $(\mathrm{Yes}=1)$ & 0.224 & 0.305 & 0.0411 \\
\hline $\begin{array}{l}\text { Number of plants planted on household } \\
\text { plot (number) }\end{array}$ & 80.466 & 217.35 & 0.0801 \\
\hline Keeping milking cows $(\mathrm{Yes}=1)$ & 0.6465 & 0.7272 & 0.0595 \\
\hline
\end{tabular}

Source: Own compilation, 2015

As expected, previous shock exposure of 2012 to 2014 (shocks due to drought, flood, theft, animal illness and death, loss of animal due to wild animal attack) for adopters is relatively higher ranging from 16 per cent for non-adopters and 28 per cent for adopters. Adopters of SF had a higher number of family members, number of plots, better access to a mobile telephone, and reside close to the nearest road than non-adopters. Adopters of SF were mainly 
male headed, had higher access to formal credit and reside far away from the free grazing area than non-adopters. Yet another comparison shows that education level, grazing area ratio, SF exposure, and access to fodder shed and animal shed are significantly different between adopters and non-adopters. Specifically, adopters have more literacy rate and significantly more SF exposure, access to fodder and animal shed. Contrary to expectations, adopters also have a higher value of farm tool and a lower feed supplementary expense than non-adopters. Adopters have more than twice as much breed cows and farm cart as their non-adopting counterparts.

\section{Endogenous Switching Regression Model}

Estimation of the economic gain of adoption of agricultural technologies such as stall feeding based on non-experimental observations is not trivial because finding a proper counterfactual to treatment is the main challenge in impact evaluation. Adoption is a voluntary decision where farmers themselves decide to adopt or not to adopt based on the information they have. Therefore, adopters and non-adopters may be systematically different. When comparing adopters with non-adopters, adopters might differ on additional unobservable characteristics such as ability, awareness, information or motivation that could have a direct effect on the outcomes beyond adoption. That is, without stall feeding, outcomes might have been higher for adopters or lower for non-adopters as well, due to unobserved characteristics (Blundell \& Costa Dias 2000). Treating adoption as an exogenous variable and applying OLS would result in inconsistent parameter estimate.

The other econometric issue is that even if we account for the endogeneity, it may not be proper to use a pooled model estimation which assumes that the set of covariates has the same impact on adopters and nonadopters. If it is assumed that covariates have differential effects on household outcome, separate welfare outcome functions for adopters and non-adopters have to be specified. The econometric problem will, therefore, contain both endogeneity (Hausman, 1978) and sample selection (Heckman, 1979). More generally, the problem is that farmers in each of the two regimes are not the same with respect to variables that are correlated to the error term. This motivated the researchers to employ an ESR model used by Alene and Manyong (2007) following Lokshin and Sajaia (2004) which allows the researcher not only to simultaneously estimate the binary and continuous parts of the model in order to yield consistent standard errors but also to account for both endogeneity and sample selection bias based on joint normality of the error terms assumption.

Basically, ESR has two steps: the first step in the ESR is to specify the selection model so as to determine factors influencing stall feeding adoption based on a probit function as specified by Equation (11).

$$
\begin{aligned}
& D_{i}^{*}=Z_{i} \gamma+\varepsilon_{i} \\
& D_{i}=1 \text { if } D_{i}^{*}>0 \quad \text { (Adoption of stall feeding) }
\end{aligned}
$$




$$
D_{i}=0 \text { if } D_{i}^{*} \leq 0 \quad \text { (non }- \text { adoption of stall feeding) }
$$

Where, $D_{i}^{*}$, is the latent variable for stall feeding adoption, $D_{i}$ is its observable counterpart equals one if the farmer has adopted SF, and zero otherwise, $Z_{i}$ are vectors of exogenous farm and non-farm characteristics determining adoption and $\varepsilon_{i}$ is random disturbances associated with the adoption. The second step in the ESR is to define a separate outcome functions for the two groups. The welfare functions can be expressed as:

Regime 1: $Y_{1 i}=X_{1 i} \beta_{1}+e_{1 i}$ if $D_{i}=1$ (outcome of stall feeding users)

Regime 2: $Y_{2 i}=X_{2 i} \beta_{2}+e_{2 i}$ if $D_{i}=0$ (outcome of non-users of stall feeding)

$X_{1}$ and $X_{2}$ are vectors of weakly exogenous variables. $\beta_{1}$ and $\beta_{2}$ are vectors of parameters; and $e_{1}$ and $e_{2}$ are random disturbance terms. $Y_{i}$, represents outcomes measured in terms of milk produced and consumed, lactation period and animal market participation etc. Unfortunately both $Y_{1}$ and $Y_{2}$ can not be observed for a single animal at the same time. But the difference between the two is exactly what the author intend to discover, that is, the author is interested in (I) the difference between the outcome of the user and their expected outcome had they not practiced stall feeding, and (II) the difference between the benefit of the non-user and their expected benefit had they adopted stall feeding. The mathematical explanation of these outcomes can be presented as:

$$
Y_{1 i}-\mathrm{E}\left(Y_{2 i} \mid D_{i}=1\right) \text { (benefit of adopters) }
$$

$Y_{2 i}-\mathrm{E}\left(Y_{1 i} \mid D_{i}=0\right)$ (forgone benefit of non-adopters)

Assuming that $\varepsilon_{i}, e_{1 i}$ and $e_{2 i}$ have a trivariate normal distribution, with mean vector zero and covariance matrix:

$$
\operatorname{Cov}\left(\varepsilon_{1}, \varepsilon_{2}, \varepsilon_{0}\right)=\left[\begin{array}{ccc}
\sigma_{0}^{2} & \sigma_{01} & \sigma_{02} \\
\sigma_{10} & \sigma_{1}^{2} & \cdot \\
\sigma_{20} & . & \sigma_{2}^{2}
\end{array}\right]
$$

Where $\sigma_{1}^{2}$ and $\sigma_{2}^{2}$ are variances of the error terms, $e_{1}$ and $e_{2} ; \sigma_{0}^{2}$ is the variance of the error term, $\varepsilon_{0}$ which can be assumed to be equal to 1 since the coefficients are estimable only up to a scale factor (Lokshin \& Sajaia, 2004); $\sigma_{10}$ is the covariance of $e_{1}$ and $\varepsilon_{0}$, and $\sigma_{20}$ is the covariance of $\varepsilon_{2}$ and $\varepsilon_{0}$. Since $Y_{1}$ and $Y_{2}$ are never observed simultaneously at the same time in a single cow or ox, the covariance between $\varepsilon_{1}$ and $\varepsilon_{2}$ is not defined and therefore indicated as dots in the covariance matrix and since the error term of the selection equation is correlated with the error terms of the outcome functions, the expected values of $e_{1}$ and $e_{2}$ conditional on the sample selection are nonzero and are defined as: 


$$
\begin{aligned}
& E\left[e_{1 i} \mid D_{i}=1\right]=\sigma_{10} \frac{\phi\left(Z_{i} \gamma\right)}{\Phi\left(Z_{i} \gamma\right)}=\sigma_{10} \eta_{1 i} \\
& E\left[e_{1 i} \mid D_{i}=0\right]=\sigma_{20} \frac{\phi\left(Z_{i} \gamma\right)}{\Phi\left(Z_{i} \gamma\right)}=\sigma_{20} \eta_{2 i}
\end{aligned}
$$

Where $\phi($.$) and \Phi($.$) are the standard normal probability density$ function and normal cumulative density function respectively. In this case, a statistical significance of the two estimated covariance, $\hat{\sigma}_{10}$ and $\hat{\sigma}_{20}$ indicates that the decision to adopt and outcome variable are correlated implying the presence of endogenous switching and the null hypothesis of the absence of sample selectivity bias is rejected. Full Information Maximum Likelihood (FIML) method was employed for our estimation as it is a more efficient method of estimating endogenous switching regression models (Lokshin \& Sajaia, 2004). The logarithmic likelihood functions are given the assumption of trivariate normal distribution for the error terms:

$$
\begin{aligned}
& \ln L_{i}=\sum_{i=1}^{N}\left\{D_{i}\left[\ln \phi\left(\frac{e_{1 i}}{\sigma_{1}}\right)-\ln \sigma_{1}+\ln \Phi\left(\theta_{1 i}\right)\right]+\left(1-D_{i}\right)\left[\ln \phi\left(\frac{e_{2 i}}{\sigma_{2}}\right)-\right.\right. \\
& \left.\left.\ln \sigma_{2}+\ln \left(1-\Phi\left(\theta_{2 i}\right)\right)\right]\right\}
\end{aligned}
$$

Where $\theta_{j i}=\frac{z_{i} \gamma+\rho_{j} \varepsilon_{j i} / \sigma_{j}}{\sqrt{1-\rho_{j}^{2}}} \frac{1}{2}$, with $\mathrm{j}=1,2$, and $\rho_{j}$ represents the correlation coefficient between the error terms $\varepsilon_{i}$ of the selection model and the error terms $e_{1 i}$ and $e_{2 i}$ of the outcome equation. Even if there is only one dependent variable, the set of exogenous variables in the first regression might be different from the set of exogenous variables in the second regression. Hence, both equations must be specified (Lokshin \& Sajaia, 2004). In addition, we followed the usual order condition that $Z_{i}$ contain at least one variable not in $X_{i}$ imposing an exclusion restriction on Equation (14). These variables do not have any direct effect on the outcome variable, although they are hypothesized to affect the probability that the household adopts improved technology.

The use of endogenous switching regression model has an additional advantage in comparing the expected outcome of adopters (I) with respect to the households that did not adopt (II), and to investigate the expected outcome in the counterfactual hypothetical cases (III) that the adopted households did not adopt, and (IV) that the non-adopters households adopted. Thus, the conditional expectations for our outcome variables in the four cases are denoted as:

(I) $\quad E\left(Y_{1 i} \mid D_{i}=1\right)=X_{1 i} \beta_{1}+\sigma_{10} \eta_{1 i}$

(II) $\quad E\left(Y_{2 i} \mid D_{i}=0\right)=X_{2 i} \beta_{2}+\sigma_{20} \eta_{2 i}$

(III) $E\left(Y_{2 i} \mid D_{i}=1\right)=X_{1 i} \beta_{2}+\sigma_{20} \eta_{1 i}$

(IV) $E\left(Y_{1 i} \mid D_{i}=0\right)=X_{2 i} \beta_{1}+\sigma_{10} \eta_{2 i}$

Cases (I) and (II) indicates the actual expectations observed in the sample whereas cases (III) and (IV) represent the counterfactual expected 
outcomes. Furthermore, the effect of the treatment 'to adopt' on the treated (TT) is calculated as the difference between (I) and (III), and the effect of the treatment of the untreated (TU) for the households that actually did not adopt as the difference between (IV) and (II) the procedures taken by Heckman (2001), and Di Falco and Veronesi (2013) that compares the performance of climate change adaptation strategies in Ethiopian agriculture via calculating adopters from adaption (ATT) and non-adopters had they adoption (ATU). We also label $\mathrm{BH}_{1}$ as "the effect of base heterogeneity" for the group of farmers who decided to adapt as the difference between (I) and (II). In a similar fashion, $\mathrm{BH}_{2}$ for those farm households who decided not to adapt and calculated as the difference between (III) and (II).

(II) $\quad T T=E\left(Y_{1 i} \mid D_{i}=1\right)-E\left(Y_{2 i} \mid D_{i}=1\right)=X_{1 i}\left(\beta_{1}-\beta_{2}\right)+\left(\sigma_{10}-\right.$ $\left.\sigma_{20}\right) \eta_{1 i}$

(III) $\quad T U=E\left(Y_{1 i} \mid D_{i}=0\right)-E\left(Y_{2 i} \mid D_{i}=0\right)=X_{2 i}\left(\beta_{1}-\beta_{2}\right)+\left(\sigma_{10}-\right.$ $\left.\sigma_{20}\right) \eta_{2 i}$

(IV) $\quad B H_{1}=\left(Y_{1 i} \mid D_{i}=1\right)-E\left(Y_{1 i} \mid D_{i}=0\right)=\left(X_{1 i}-X_{2 i}\right) \beta_{1 I}+$ $\sigma_{10}\left(\eta_{1 i}-\eta_{2 i}\right)$

(V) $\quad B H_{2}=\left(Y_{1 i} \mid D_{i}=1\right)-E\left(Y_{2 i} \mid D_{i}=1\right)=\left(X_{1 i}-X_{2 i}\right) \beta_{2 I}+$ $\sigma_{20}\left(\eta_{1 i}-\eta_{2 i}\right)$

\section{Empirical Results}

We first focus on the adoption of SF in the selection equation (11). Second, we explain the factors affecting the outcome variables estimated by equations (12), depending on whether farmers are adopters or non-adopters. Finally, we estimate ATT for adopters and ATU for non-adopters by equation (16).

\section{Determinates of Adoption and Outcome Variables}

The estimates of the determinants of adoption and outcome variables are presented in Tables 2. As noted previously, the FIML method estimates both the adoption and the outcome equations jointly. Results from the selection equations are discussed first. The estimate results for the probability of adopting the technology are generally in agreement with our earlier expectation. In all specifications, the same variables almost have statistically similar effects on adoption. The correlation coefficients $\left(\rho_{1}\right.$ and $\left.\rho_{2},\right)$ between the error terms of the selection and outcome equations are reported at the bottom section of the same table as an indication of selection bias. A statistical significance of any of them signalled to accounted for self-selection issue. The correlation coefficients for the adopters $\left(\rho_{1}\right)$ and non-adopters $\left(\rho_{2}\right)$ equations are both negative but statistically insignificant, suggesting that both groups are not better or worse off than a random farm household. The insignificance of the likelihood ratio tests for independence of equations also proved that there is no joint dependence between the selection equations and the outcome equations for adopters and non-adopters (Table 2) as in the case of Di Falco and Veronesi (2013). 
However, the differences in the milk production (Table 2) and consumption (Table 3) equation coefficients between the farm households that adopted and those that did not adopt illustrate the presence of heterogeneity in the sample. The selection results are only discussed briefly as our main objective is to evaluate the impacts on different outcomes. Column (3) of Table 2 shows that factors influencing the household decision to participate in FSF are: zonal variation and access to information, animal feed shed, breed cow, village exposure to SF, animal shock and location; forage use and total feed value. The variable representing access to information is positive and significantly different from zero, suggesting that more-informed farmers are more likely to adopt FSF. This finding is consistent with the findings of (Deressa et al., 2009; Gunte, 2015; Hadush 2018), who revealed a positive relation between access to information and technology adoption in Ethiopia. The variable access to animal feed shed is also positive and statistically significant in the selection model, indicating that farmers with feed shed are more likely to adopt the technology.

The possession of improved cow and previous animal shock exposure, forage expense and total feed value are statistically significant with a positive sign, inducing farming households to adopt SF technology. As noted by Turinawe et al., (2011) in Uganda and Hadush (2018). In Ethiopia, adoption of SF was significantly and positively influenced by the number of breed cows, and relevant findings of Holden and Westberg (2016) indicated that cereal plantation and fertilizer application were positively correlated with risk aversion for net buyers of food in Ethiopia. Ayenew et al., (2015), found that farmers with a higher level of relative risk premium were more likely to opt for crop diversification in Ethiopia. Farmers living in lowlands area showed more interest in the SF use and this opposes the results of Bishu (2014) once zonal variation is controlled.

Smallholder farmers in Ethiopia mainly depend on grazing land and crop residue to feed their animals (Tegegne et al., 2013). The estimation results show that grazing area ratio, access to animal feed shed and breed cow positively affect the milk production of adopters. Makoni et al., (2014) argue that the increase in milk production may have come mainly from increased number of cows rather than increased productivity while Adane et al., (2015) indicated that higher grazing land and number of breed cows per household were positively associated with the higher the milk output in Ethiopia.

The variables hired labour and family labour had opposite signs with hired labour having a negative effect and family labour having a positive effect on milk output of non-adopters. Adane et al., (2015) and Del Corral et al., (2011) found that there is a strong relationship between family labour and milk production. In addition, the agro-ecology variation in which household reside determines the level of household milk production for both groups negatively. The availability of fodder shed and purchased supplements are also found to have unexpected negative effects on milk production mainly for adopters. This 
result is inconsistent with other studies on milk production (Del Corral et al., 2011; Adane et al., 2015).

\section{Table 2: Endogenous switching for FSF adoption and milk production}

\begin{tabular}{|c|c|c|c|}
\hline Variable & $\begin{array}{c}(\mathrm{FSF}=1) \\
\text { Milk yield }\end{array}$ & $\begin{array}{c}(\mathrm{FSF}=0) \\
\text { Milk yield }\end{array}$ & $\begin{array}{l}(\mathrm{FSF}=1 / 0) \\
\text { Selection }\end{array}$ \\
\hline \multirow[t]{2}{*}{ Province5 (South East) } & -0.463 & $-0.770 * * *$ & $0.948 * *$ \\
\hline & $(0.309)$ & $(0.182)$ & $(0.370)$ \\
\hline \multirow[t]{2}{*}{ Province 3 (Central) } & $-0.748 * * *$ & $-0.826 * * *$ & $1.564 * * *$ \\
\hline & $(0.270)$ & $(0.275)$ & $(0.396)$ \\
\hline \multirow[t]{2}{*}{ Province 2(Eastern) } & $-0.683 * * *$ & $-0.887 * * *$ & $0.760 * *$ \\
\hline & $(0.222)$ & $(0.187)$ & $(0.353)$ \\
\hline \multirow[t]{2}{*}{ Province 4 (North west) } & -0.396 & $-0.685 * * *$ & $0.458 *$ \\
\hline & $(0.257)$ & $(0.143)$ & $(0.252)$ \\
\hline \multirow[t]{2}{*}{ Total cows (count) } & 0.0316 & -0.0367 & -0.0534 \\
\hline & $(0.0618)$ & $(0.0268)$ & $(0.0690)$ \\
\hline \multirow[t]{2}{*}{ Hired labour $($ Yes $=1)$} & 0.138 & $-0.240 * * *$ & 0.0499 \\
\hline & $(0.140)$ & $(0.0902)$ & $(0.178)$ \\
\hline \multirow[t]{2}{*}{ Grazing area to household ratio (ha/hh) } & $48.27 * *$ & 13.99 & -35.00 \\
\hline & $(24.02)$ & $(13.73)$ & $(49.72)$ \\
\hline \multirow[t]{2}{*}{ Total animal feed value (ETB) } & $-9.02 \mathrm{e}-06$ & $1.06 \mathrm{e}-05$ & $3.43 \mathrm{e}-05 * * *$ \\
\hline & $(1.01 \mathrm{e}-05)$ & $(8.00 \mathrm{e}-06)$ & $(1.15 \mathrm{e}-05)$ \\
\hline \multirow[t]{2}{*}{ Forage expense (ETB) } & -0.0657 & -0.00264 & $0.357 *$ \\
\hline & $(0.159)$ & $(0.114)$ & $(0.183)$ \\
\hline \multirow[t]{2}{*}{ Feed supplementary cost (ETB) } & 0.000250 & $-0.000161 * * *$ & $-1.00 \mathrm{e}-05$ \\
\hline & $(0.000154)$ & $(5.25 \mathrm{e}-05)$ & $(0.000153)$ \\
\hline \multirow[t]{2}{*}{ Veterinary expense (ETB) } & -0.00144 & 0.000406 & -0.000599 \\
\hline & $(0.00148)$ & $(0.000263)$ & $(0.000755)$ \\
\hline \multirow[t]{2}{*}{ Location(Highland=1) } & 0.241 & 0.155 & $-0.754 *$ \\
\hline & $(0.237)$ & $(0.206)$ & $(0.448)$ \\
\hline \multirow[t]{2}{*}{ Improved cow $($ Yes $=1)$} & $0.471 *$ & -0.381 & $1.556 * * *$ \\
\hline & $(0.278)$ & $(0.271)$ & $(0.383)$ \\
\hline \multirow[t]{2}{*}{ Access to pond $(\mathrm{Yes}=1)$} & -0.140 & $-0.387 *$ & -0.449 \\
\hline & $(0.200)$ & $(0.233)$ & $(0.767)$ \\
\hline \multirow[t]{2}{*}{ Access to animal shed $(\mathrm{Yes}=1)$} & $0.520 * *$ & -0.161 & 0.336 \\
\hline & $(0.209)$ & $(0.141)$ & $(0.334)$ \\
\hline \multirow[t]{2}{*}{ Access to fodder shed $(Y e s=1)$} & $-0.534 * * *$ & $-0.605 * *$ & $1.732 * *$ \\
\hline & $(0.161)$ & $(0.255)$ & $(0.699)$ \\
\hline \multirow[t]{2}{*}{ Household head age (year) } & 0.000937 & 0.00166 & -0.00430 \\
\hline & $(0.00523)$ & $(0.00289)$ & $(0.00578)$ \\
\hline \multirow[t]{2}{*}{ Animal shock exposure $(\mathrm{Yes}=1)$} & -0.122 & 0.189 & $0.473 * *$ \\
\hline & $(0.177)$ & $(0.116)$ & $(0.188)$ \\
\hline \multirow[t]{2}{*}{ Family labour (Hours) } & 0.00203 & $0.00107 *$ & 0.000891 \\
\hline & $(0.00123)$ & $(0.000550)$ & $(0.00105)$ \\
\hline \multirow[t]{2}{*}{ Information access (Yes $=1)$} & & & $0.381 * *$ \\
\hline & & & $(0.186)$ \\
\hline \multirow[t]{2}{*}{ Village exposure to SF (years) } & & & $0.144 * *$ \\
\hline & & & $(0.0705)$ \\
\hline Constant & $2.081 * * *$ & $1.863 * * *$ & $-1.638 * * *$ \\
\hline & $(0.381)$ & $(0.182)$ & $(0.464)$ \\
\hline $\operatorname{lns} 1, \ln s 2$ & - & $-0.556(0.164)^{* * *}$ & \\
\hline & $0.271(0.132) * *$ & & \\
\hline$\rho_{1}, \rho_{2}$ & $-0.363(0.266)$ & $0.166(0.354)$ & \\
\hline LR test of indep. eqns (PV & & 0.2058 & \\
\hline Observations & 364 & 364 & 364 \\
\hline
\end{tabular}


Table 3: Endogenous switching for FSF adoption and milk and meat consumption expenditure

\begin{tabular}{|c|c|c|c|}
\hline Variable & $\begin{array}{c}(\mathrm{FSF}=1) \\
\text { Consumption }\end{array}$ & $\begin{array}{c}(\mathrm{FSF}=0) \\
\text { Consumption }\end{array}$ & $\begin{array}{l}(\mathrm{FSF}=1 / 0) \\
\text { Selection }\end{array}$ \\
\hline Family size (count) & $\begin{array}{r}18.36 \\
(98.52)\end{array}$ & $\begin{array}{r}31.65 \\
(4764)\end{array}$ & $\begin{array}{r}0.0445 \\
(0.0332)\end{array}$ \\
\hline Household head sex & $751.5 * *$ & -102.2 & $0.401 *$ \\
\hline$($ Male $=1)$ & $(341.2)$ & $(262.0)$ & $(0.214)$ \\
\hline Household head age & -16.44 & 5.832 & -0.00239 \\
\hline (year) & $(10.13)$ & $(8.664)$ & $(0.00513)$ \\
\hline Household head education & -374.3 & -99.19 & 0.0350 \\
\hline$($ literate $=1)$ & (362.6) & (298.7) & $(0.155)$ \\
\hline Total food Expenditure & $0.0823 * * *$ & $0.0413 * * *$ & $1.81 \mathrm{e}-06$ \\
\hline$(\mathrm{ETB})$ & $(0.0208)$ & $(0.0138)$ & $(3.19 \mathrm{e}-06)$ \\
\hline Farm size(ha) & $\begin{array}{r}-63.41 \\
(84.29)\end{array}$ & $\begin{array}{r}71.42 \\
(155.7)\end{array}$ & $\begin{array}{r}0.0310 \\
(0.0582)\end{array}$ \\
\hline Total farm income (ETB) & $\begin{array}{r}0.0401 \\
(0.0381)\end{array}$ & $\begin{array}{r}-0.00273 \\
(0.00253)\end{array}$ & $\begin{array}{r}-7.93 \mathrm{e}-06 \\
(6.06 \mathrm{e}-06)\end{array}$ \\
\hline $\begin{array}{l}\text { Total off farm income } \\
\text { (ETB) }\end{array}$ & $\begin{array}{r}0.0226 \\
(0.0187)\end{array}$ & $\begin{array}{r}-0.00336 \\
(0.00315)\end{array}$ & $\begin{array}{r}-3.90 \mathrm{e}-06 \\
(5.67 \mathrm{e}-06)\end{array}$ \\
\hline $\begin{array}{l}\text { Religion of household } \\
\text { head (Orthodox }=1 \text { ) }\end{array}$ & $\begin{array}{r}-593.2 \\
(623.1)\end{array}$ & $\begin{array}{r}-51.60 \\
(317.1)\end{array}$ & $\begin{array}{r}0.488 * * \\
(0.211)\end{array}$ \\
\hline $\begin{array}{l}\text { Location of household } \\
(\text { Highland=1) }\end{array}$ & $\begin{array}{r}713.0 \\
(791.4)\end{array}$ & $\begin{array}{r}-174.8 \\
(203.5)\end{array}$ & $\begin{array}{r}-1.080 * * \\
(0.451)\end{array}$ \\
\hline $\begin{array}{l}\text { Information access (TV, } \\
\text { Radio \& mobile }=1 \text { ) }\end{array}$ & $\begin{array}{r}148.6 \\
(395.2)\end{array}$ & $\begin{array}{r}124.4 \\
(357.8)\end{array}$ & $\begin{array}{r}0.546 * * * \\
(0.183)\end{array}$ \\
\hline Herd size(TLU) & $\begin{array}{r}155.4 * * * \\
(59.18)\end{array}$ & $\begin{array}{r}186.9 * * * \\
(49.73)\end{array}$ & $\begin{array}{r}-0.0216 \\
(0.0237)\end{array}$ \\
\hline $\begin{array}{l}\text { Access to formal credit } \\
(Y e s=1)\end{array}$ & $\begin{array}{r}737.2 \\
(482.0)\end{array}$ & $\begin{array}{r}122.5 \\
(272.3)\end{array}$ & $\begin{array}{r}-0.0302 \\
(0.168)\end{array}$ \\
\hline $\begin{array}{l}\text { Animal shock experience } \\
(\text { Yes }=1)\end{array}$ & $\begin{array}{r}-182.0 \\
(363.8)\end{array}$ & $\begin{array}{r}-130.3 \\
(362.8)\end{array}$ & $\begin{array}{l}0.338 * \\
(0.183)\end{array}$ \\
\hline $\begin{array}{l}\text { Distance to free grazing } \\
\text { land (walking minute) }\end{array}$ & & & $\begin{array}{r}0.00168 \\
(0.00183)\end{array}$ \\
\hline Exposure of SF(years) & & & $\begin{array}{r}0.322 * * * \\
(0.0560)\end{array}$ \\
\hline Constant & $\begin{array}{r}1,038 \\
(1,251)\end{array}$ & $\begin{array}{r}-261.2 \\
(503.9)\end{array}$ & $\begin{array}{r}-2.587 * * * \\
(0.503)\end{array}$ \\
\hline $\operatorname{lns} 1, \operatorname{lns} 2$ & $7.552(0.045)^{* * *}$ & $7.527(0.0001)^{* * * *}$ & \\
\hline $\begin{array}{l}\rho_{1}, \rho_{2} \\
\text { LR test of indep. eqns } \\
\text { (PV }\end{array}$ & $-0.318(0.280)$ & $\begin{array}{r}0.0023(0.124) \\
0.1434\end{array}$ & \\
\hline Observations & 364 & 364 & 364 \\
\hline
\end{tabular}

Referring to Table 3, the ESR estimate for the milk and meat product consumption expenditure indicated that the correlation coefficients between the error terms in the selection and the outcome equations $\left(\rho_{1}\right.$ and $\left.\rho_{2}\right)$ are not statistically different from zero - implying that the switch is not endogenous. 
Expectedly, an increase in household herd size results in increment of 155 ETB consumption expenditure for adopters while higher total food expenditure contributes positively to expenditure on milk and meat products. This finding is in consonance with economic theory, which posits that farmers with higher asset spend more on consumer goods and is in conformity with the literature findings of milk consumption expenditure (Aidoo et al., 2009; Oni \& Fashogbon, 2012).

A similar relationship was also reported in Kenya where dairy cow ownership increased consumption of milk products by 1.0 litre per week (Nicholson et al., 2004). The results also showed that adopting male farmers recorded a significant consumption expenditure in milk and milk products in line with the results of Oni and Fashogbon (2012). A positive effect was observed between household total food expenditure and milk consumption expenditure. This finding was in agreement with the result of Oni and Fashogbon (2012), where they reported that as food expenditure increases the consumption of milk and milk products expenditure increases in Nigeria.

The ESR empirical results for the probability of participating in animal and animal product sale in Table 4 showed that participation in animal and animal products markets were influenced to a great extent by family size, distance to market, cattle size, population density, animal shock, agroecological location and agro-ecology variation and not so much by farmers 'literacy. Farmers with more family member and cow number living in the highland participated more in an animal market. However, ownership of oxen and animal shock experience reduced participation in the market for animals and animal product. These findings reinforce the findings of Ehui et al., (2003) and Kuma et al., (2014) where they found that oxen holding reduced dairy product sale while cow stock increased live animal or dairy product sale in Ethiopia.

Table 4: Endogenous switching for FSF adoption and animal sale market participation

\begin{tabular}{lrrr}
\hline Variable & $\begin{array}{c}(\mathrm{FSF}=1) \\
\text { Participation }\end{array}$ & $\begin{array}{c}(\mathrm{FSF}=0) \\
\text { Participation }\end{array}$ & \multicolumn{1}{c}{$\begin{array}{c}\text { (FSF=1/0) } \\
\text { Selection }\end{array}$} \\
\hline Distance to market (walking & 0.000197 & $0.00262^{*}$ & -0.000370 \\
minutes) & $(0.00180)$ & $(0.00137)$ & $(0.00126)$ \\
Distance to nearest road & 0.00186 & 0.000615 & $-0.00338^{*}$ \\
(walking minutes) & $(0.00260)$ & $(0.00193)$ & $(0.00187)$ \\
Population density(ratio) & -0.000125 & $-0.000142 *$ & 0.000109 \\
& $(0.000117)$ & $(8.17 \mathrm{e}-05)$ & $(8.21 \mathrm{e}-05)$ \\
Household head age (year) & 0.00356 & 0.00432 & -0.00853 \\
& $(0.00587)$ & $(0.00543)$ & $(0.00523)$ \\
\hline
\end{tabular}


Table 4 contd...: Endogenous switching for FSF adoption and animal sale market participation

\begin{tabular}{|c|c|c|c|}
\hline Variable & $\begin{array}{c}(\mathrm{FSF}=1) \\
\text { Participation }\end{array}$ & $\begin{array}{c}(\mathrm{FSF}=0) \\
\text { Participation }\end{array}$ & $\begin{array}{l}(\mathrm{FSF}=1 / 0) \\
\text { Selection }\end{array}$ \\
\hline Household head sex $($ Male $=1)$ & $\begin{array}{r}-0.281 \\
(0.239)\end{array}$ & $\begin{array}{r}0.0124 \\
(0.204)\end{array}$ & $\begin{array}{r}0.563 * * * \\
(0.174)\end{array}$ \\
\hline Family size (number) & $\begin{array}{r}0.00752 \\
(0.0386)\end{array}$ & $\begin{array}{r}0.0950 * * * \\
(0.0340)\end{array}$ & $\begin{array}{r}0.00707 \\
(0.0283)\end{array}$ \\
\hline $\begin{array}{l}\text { Household head education } \\
\text { (literate }=1 \text { ) }\end{array}$ & $\begin{array}{r}0.111 \\
(0.172)\end{array}$ & $\begin{array}{r}-0.0786 \\
(0.153)\end{array}$ & $\begin{array}{r}-0.0407 \\
(0.137)\end{array}$ \\
\hline Total oxen number & $\begin{array}{r}-0.0289 \\
(0.0540)\end{array}$ & $\begin{array}{r}-0.118 * * \\
(0.0572)\end{array}$ & $\begin{array}{r}0.0218 \\
(0.0440)\end{array}$ \\
\hline Total cow number & $\begin{array}{r}0.130 * \\
(0.0718)\end{array}$ & $\begin{array}{r}0.0595 \\
(0.0547)\end{array}$ & $\begin{array}{r}-0.00641 \\
(0.0458)\end{array}$ \\
\hline Farm size (ha) & $\begin{array}{r}0.101 \\
(0.114)\end{array}$ & $\begin{array}{r}-0.0839 \\
(0.0965)\end{array}$ & $\begin{array}{r}0.0646 \\
(0.0629)\end{array}$ \\
\hline Breed cow possession $(Y e s=1)$ & $\begin{array}{r}-1.028^{* * * *} \\
(0.326)\end{array}$ & $\begin{array}{l}0.0187 \\
(0.868)\end{array}$ & $\begin{array}{r}1.849 * * * \\
(0.334)\end{array}$ \\
\hline $\begin{array}{l}\text { Information access }(\mathrm{TV}, \text { radio } \& \\
\text { mobile }=1 \text { ) }\end{array}$ & $\begin{array}{r}-0.166 \\
(0.190)\end{array}$ & $\begin{array}{l}-0.196 \\
(0.216)\end{array}$ & $\begin{array}{r}0.423 * * * \\
(0.164)\end{array}$ \\
\hline Mean milk price (ETB) & $\begin{array}{r}-0.000983 \\
(0.00306)\end{array}$ & $\begin{array}{r}-0.000483 \\
(0.00210)\end{array}$ & $\begin{array}{r}-0.000862 \\
(0.00280)\end{array}$ \\
\hline Social network (got assistance $=1$ ) & $\begin{array}{r}-1.48 \mathrm{e}-06 \\
(1.71 \mathrm{e}-05)\end{array}$ & $\begin{array}{l}-1.34 \mathrm{e}-05 \\
(1.72 \mathrm{e}-05)\end{array}$ & $\begin{array}{r}1.38 \mathrm{e}-05 \\
(1.63 \mathrm{e}-05)\end{array}$ \\
\hline Access to formal credit(Yes=1) & $\begin{array}{r}-0.0837 \\
(0.192)\end{array}$ & $\begin{array}{r}0.0857 \\
(0.168)\end{array}$ & $\begin{array}{r}0.0689 \\
(0.144)\end{array}$ \\
\hline Province 1(Southern) & $\begin{array}{r}1.106^{* *} \\
(0.439)\end{array}$ & $\begin{array}{r}0.439 \\
(0.362)\end{array}$ & $\begin{array}{r}-1.383 * * * \\
(0.300)\end{array}$ \\
\hline Province 2(Eastern) & $\begin{array}{r}-0.127 \\
(0.268)\end{array}$ & $\begin{array}{r}-0.0886 \\
(0.288)\end{array}$ & $\begin{array}{r}-0.459^{*} \\
(0.279)\end{array}$ \\
\hline Province 3( Central) & $\begin{array}{r}-0.146 \\
(0.267)\end{array}$ & $\begin{array}{r}-0.150 \\
(0.463)\end{array}$ & $\begin{array}{r}0.510^{*} \\
(0.265)\end{array}$ \\
\hline Province 4(North west) & $\begin{array}{l}0.502^{*} \\
(0.277)\end{array}$ & $\begin{array}{r}0.189 \\
(0.275)\end{array}$ & $\begin{array}{r}-0.580 * * * \\
(0.221)\end{array}$ \\
\hline $\begin{array}{l}\text { Location of household } \\
\text { (Highland=1) }\end{array}$ & $\begin{array}{r}0.601 * \\
(0.339)\end{array}$ & $\begin{array}{r}0.613^{* *} \\
(0.310)\end{array}$ & $\begin{array}{r}-0.585^{* *} \\
(0.296)\end{array}$ \\
\hline Animal shock experience $(\mathrm{Yes}=1)$ & $\begin{array}{r}-0.527 * * * \\
(0.197)\end{array}$ & $\begin{array}{r}-0.120 \\
(0.211)\end{array}$ & $\begin{array}{r}0.435 * * * \\
(0.159)\end{array}$ \\
\hline $\begin{array}{l}\text { Distance to free grazing land } \\
\text { (walking minute) }\end{array}$ & & & $\begin{array}{r}0.00515^{* * * *} \\
(0.00152)\end{array}$ \\
\hline Exposure of SF(years) & & & $\begin{array}{r}0.214 * * * \\
(0.0504)\end{array}$ \\
\hline Constant & $\begin{array}{r}0.698 \\
(0.467)\end{array}$ & $\begin{array}{r}-0.899 * \\
(0.503)\end{array}$ & $\begin{array}{r}-1.356 * * * \\
(0.506)\end{array}$ \\
\hline$\rho_{1}, \rho_{2}$ & $\begin{array}{r}-14.19 \\
(1.550)^{* * *}\end{array}$ & $-0.625(0.519)$ & \\
\hline LR test of indep. eqns (PV & & 0.0005 & \\
\hline Observations & 518 & 518 & 518 \\
\hline
\end{tabular}

A negative relationship was also reported between population density and market participation (Ehui et al., 2003). In a similar study area, Ehui et al., (2003) also showed that farmer participation in livestock markets sales was 
positively associated with longer distance to market and higher population density. As expected, animal shock exposure was found to have an inverse relationship with participation in the animal market. However, farmers living in the highland unexpectedly appeared to have a high probability of participation in an animal sale market than people from the lowland (Tegebu et al., 2012). In confirming with our expectation, belonging to Southern and Northwestern zones, which are relatively endowed with population livestock in the region, increased the probability of participating in an animal market.

The ESR second-stage results as presented in Table 5 displayed that propensity to grow trees was significantly affected by some factors. The result clearly indicated that household size and family labour were positively and significantly correlated with the propensity to growing trees while hired labour results in lower willingness to plant trees. This finding is consistent with earlier studies by Alamirew (2011) and Gessese et al., (2016), who both reported that family size had a positive and significant influence in adopting land management technology (tree planting) in Ethiopia As shown in Table 5, distance to nursery and access to animal cart had negative and significant influences on tree-planting decisions in contrast to studies which confirmed that there was a positive and significant relationship between farm tool and land management technology adoption (Teshome et al., 2016) in Ethiopia. The probability of growing trees was also strongly correlated with household head's age in contrast with Gessese et al., (2016).

Table 5: Endogenous switching for FSF adoption and propensity to plant

\begin{tabular}{lrrr}
\hline Variable & $\begin{array}{c}(\mathrm{FSF}=1) \\
\text { Propensity to } \\
\text { plant }\end{array}$ & $\begin{array}{c}\text { (FSF=0) } \\
\text { Propensity to } \\
\text { plant }\end{array}$ & $\begin{array}{c}\text { (FSF=1/0) } \\
\text { Selection }\end{array}$ \\
\hline Family size (number) & 0.0877 & $0.0922^{* *}$ & $0.0718^{* *}$ \\
Household head age (year) & $(0.0580)$ & $(0.0424)$ & $(0.0281)$ \\
& $0.0157 * *$ & 0.00745 & -0.00516 \\
Household head sex & $(0.00789)$ & $(0.00612)$ & $(0.00446)$ \\
(Male=1) & -0.0956 & -0.160 & $0.427 * *$ \\
Household head education & $(0.309)$ & $(0.234)$ & $(0.183)$ \\
(literate=1) & 0.214 & 0.104 & -0.0620 \\
Distance to nearest nursery & $(0.226)$ & $(0.184)$ & $(0.139)$ \\
(walking minutes) & $-0.00501 * *$ & $-0.00360 *$ & 0.000621 \\
Social network( got & $(0.00216)$ & $(0.00201)$ & $(0.00133)$ \\
assistance=1) & $-3.13 \mathrm{e}-06$ & $-2.62 \mathrm{e}-05$ & $7.09 \mathrm{e}-06$ \\
Farm size(ha) & $(2.60 \mathrm{e}-05)$ & $(2.53 \mathrm{e}-05)$ & $(1.21 \mathrm{e}-05)$ \\
& 0.0906 & 0.0463 & 0.00148 \\
Herd size(TLU) & $(0.0575)$ & $(0.109)$ & $(0.0532)$ \\
& -0.00372 & -0.0267 & -0.0274 \\
& $(0.0391)$ & $(0.0331)$ & $(0.0241)$ \\
\hline
\end{tabular}


Table 5 contd...: Endogenous switching for FSF adoption and propensity to plant

\begin{tabular}{|c|c|c|c|}
\hline Variable & $\begin{array}{l}(\mathrm{FSF}=1) \\
\text { Propensity } \\
\text { to plant }\end{array}$ & $\begin{array}{c}(\mathrm{FSF}=0) \\
\text { Propensity to } \\
\text { plant }\end{array}$ & $\begin{array}{l}(\mathrm{FSF}=1 / 0) \\
\text { Selection }\end{array}$ \\
\hline $\begin{array}{l}\text { Information access (TV, } \\
\text { radio } \& \text { mobile }=1)\end{array}$ & $\begin{array}{r}0.0354 \\
(0.272)\end{array}$ & $\begin{array}{r}-0.0538 \\
(0.283)\end{array}$ & $\begin{array}{r}0.536^{* * * *} \\
(0.163)\end{array}$ \\
\hline Family Labour (hr) & $\begin{array}{r}0.00270 \\
(0.00181)\end{array}$ & $\begin{array}{l}0.00212 * \\
(0.00115)\end{array}$ & $\begin{array}{r}0.000698 \\
(0.000917)\end{array}$ \\
\hline Hired Labour (Yes=1) & $\begin{array}{r}-0.726 * * * \\
(0.264)\end{array}$ & $\begin{array}{r}-0.229 \\
(0.194)\end{array}$ & $\begin{array}{r}-0.119 \\
(0.140)\end{array}$ \\
\hline $\begin{array}{l}\text { Location of household } \\
(\text { Highland }=1)\end{array}$ & $\begin{array}{r}-0.0732 \\
(0.416)\end{array}$ & $\begin{array}{r}0.0230 \\
(0.341)\end{array}$ & $\begin{array}{r}-0.944 * * * \\
(0.332)\end{array}$ \\
\hline $\begin{array}{l}\text { Access to animal cart } \\
(\mathrm{Yes}=1)\end{array}$ & $\begin{array}{l}0.0314 \\
(0.281)\end{array}$ & $\begin{array}{r}-6.662 * * * \\
(0.309)\end{array}$ & $\begin{array}{r}0.430 * * \\
(0.202)\end{array}$ \\
\hline $\begin{array}{l}\text { Willingness to invest in } \\
\text { trees (Yes }=1 \text { ) }\end{array}$ & $\begin{array}{r}-0.280 \\
(0.231)\end{array}$ & $\begin{array}{r}-0.490 * * * \\
(0.180)\end{array}$ & $\begin{array}{r}-0.00472 \\
(0.131)\end{array}$ \\
\hline $\begin{array}{l}\text { Animal shock } \\
\text { experience }(\text { Yes }=1)\end{array}$ & & & $\begin{array}{r}0.380^{* *} \\
(0.156)\end{array}$ \\
\hline Exposure of SF(year) & & & $\begin{array}{r}0.326 * * * \\
(0.0492)\end{array}$ \\
\hline Constant & $\begin{array}{r}-1.674 * * \\
(0.705)\end{array}$ & $\begin{array}{r}-1.537 * * * \\
(0.531)\end{array}$ & $\begin{array}{r}-1.939 * * * \\
(0.431)\end{array}$ \\
\hline$\rho_{1}, \rho_{2}$ & $\begin{array}{r}0.0798 \\
(0.331)\end{array}$ & $\begin{array}{r}-0.388 \\
(0.588)\end{array}$ & \\
\hline LR test of indep. eqns (PV & & 0.6843 & \\
\hline Observations & 518 & 518 & 518 \\
\hline
\end{tabular}

\section{Impact of FSF and SSF Adoption}

Estimated impacts of full and seasonal stall feeding adoption are presented in Table 6. The predicted outcomes from the ESR models are used to compute both the Average treatment effect on the treated (ATT) and Average treatment effect on the non-treated (ATU). ESR results also demonstrate that SF has mixed impacts on economic indicators (milk production and consumption, lactation period) and market participation in the animal sale and animal shock. We estimated endogenous switching regression (ESR) to control for selection bias from both observable and unobservable factors by the full information maximum likelihood (FIML) method (Lokshin $\&$ Sajaia, 2004) and model results are presented in Table 6. We first discuss the results from the continuous outcomes followed by estimates for the binary outcomes. 
Table 6: Impact of SF on economic, ecological and social welfare indicators

\begin{tabular}{|c|c|c|c|c|c|c|c|}
\hline \multirow{2}{*}{$\begin{array}{l}\text { Outcome } \\
\text { indicator }\end{array}$} & & \multicolumn{2}{|c|}{ Decision on FSF ${ }^{a}$} & \multirow{2}{*}{$\begin{array}{l}\text { Treatment } \\
\text { effect }\end{array}$} & \multicolumn{2}{|c|}{ Decision on $\mathrm{SSF}^{\mathrm{b}}$} & \multirow{2}{*}{$\begin{array}{l}\text { Treatment } \\
\text { effect }\end{array}$} \\
\hline & & adopt & $\begin{array}{l}\text { not- } \\
\text { adopt }\end{array}$ & & adopt & $\begin{array}{l}\text { not- } \\
\text { adopt }\end{array}$ & \\
\hline \multirow{2}{*}{$\begin{array}{l}\text { Milk } \\
\text { production } \\
(\mathrm{L})\end{array}$} & Participants & 2.4661 & 2.0198 & $0.4462^{* * *}$ & 1.9045 & -0.1487 & $2.0533^{* *}$ \\
\hline & $\begin{array}{l}\text { Non- } \\
\text { participants }\end{array}$ & 4.4336 & 2.1350 & $2.2986^{* * *}$ & 2.2169 & 1.2217 & $0.9952^{* * *}$ \\
\hline \multirow[t]{2}{*}{ Milk yield } & Participants & 1.6993 & 1.4064 & $0.2928^{* * *}$ & 1.7419 & -0.0210 & $1.7630^{* * *}$ \\
\hline & $\begin{array}{l}\text { Non- } \\
\text { participants }\end{array}$ & 2.1696 & 1.4592 & $0.7104^{* * *}$ & 0.2884 & 1.3935 & $-1.1051^{* * *}$ \\
\hline \multirow{2}{*}{$\begin{array}{l}\text { Lactation in } \\
\text { months }\end{array}$} & Participants & 8.4598 & 8.1712 & $0.2886^{* * *}$ & 8.3298 & 8.7293 & $-0.3995^{* * *}$ \\
\hline & $\begin{array}{l}\text { Non- } \\
\text { participants }\end{array}$ & 8.6022 & 7.6087 & $0.9935^{* * *}$ & 8.3292 & 7.2554 & $1.0737^{* * *}$ \\
\hline \multirow{2}{*}{$\begin{array}{l}\text { Milk \& Meat } \\
\text { consumption }\end{array}$} & Participants & 1855.6 & 1587.9 & $267.7^{* * * *}$ & 1807.8 & 1254.5 & $553.2^{* * *}$ \\
\hline & $\begin{array}{l}\text { Non- } \\
\text { participants }\end{array}$ & 2777.4 & 1548.9 & $1228.4^{* * *}$ & 2141.8 & 1470.3 & $671.5^{* * *}$ \\
\hline \multirow{2}{*}{$\begin{array}{l}\text { Manure use in } \\
\text { KG }\end{array}$} & Participants & 1061.1 & 767.14 & $294.01^{\text {*** }}$ & 1338.6 & 1080.5 & $258.08^{* * *}$ \\
\hline & $\begin{array}{l}\text { Non- } \\
\text { participants }\end{array}$ & 905.90 & 939.90 & -34.005 & -1421.3 & 1022.7 & $-2444^{* * *}$ \\
\hline \multirow{2}{*}{$\begin{array}{l}\text { Number of } \\
\text { trees planted }\end{array}$} & Participants & 37.434 & 25.965 & $11.468^{* * *}$ & 124.4 & 17.72 & $-9.636^{* * *}$ \\
\hline & $\begin{array}{l}\text { Non- } \\
\text { participants }\end{array}$ & 48.093 & 11.557 & $36.536^{* * * *}$ & -181.4 & 13.64 & $30.156^{* * * *}$ \\
\hline \multirow{2}{*}{$\begin{array}{l}\text { Conservation } \\
\text { structure } \\
\text { length }\end{array}$} & Participants & 121.24 & 91.955 & $29.287^{* *}$ & 114.30 & 100.79 & 13.504 \\
\hline & $\begin{array}{l}\text { Non- } \\
\text { participants }\end{array}$ & 224.37 & 90.382 & $133.98^{* * *}$ & 140.18 & 85.550 & $54.635^{* * *}$ \\
\hline \multirow[t]{2}{*}{ Plant (1/0) } & Participants & ATT & & $0.1939^{* * *}$ & & & $0.0819^{* * * *}$ \\
\hline & $\begin{array}{l}\text { Non- } \\
\text { participants }\end{array}$ & ATU & & 0.0063 & & & $0.1256^{* * * *}$ \\
\hline \multirow{2}{*}{$\begin{array}{l}\text { Animal sale } \\
(1 / 0)\end{array}$} & Participants & ATT & & $0.2945^{* * *}$ & & & $0.1604^{* * *}$ \\
\hline & $\begin{array}{l}\text { Non- } \\
\text { participants }\end{array}$ & ATU & & $0.4782^{* * *}$ & & & $0.4061^{* * *}$ \\
\hline
\end{tabular}

NB: $\mathrm{P}$ values are for slopes: $* * * \mathrm{P}<0.01, * * \mathrm{P}<0.05$, and $* \mathrm{P}<0.10=$ significant at $1 \%, 5 \%$, and $10 \%$ probability level, respectively; ${ }^{\mathrm{a}} \mathrm{FSF}=\mathrm{Full}$ year Stall Feeding adoption and ${ }^{\mathrm{b}} \mathrm{SSF}=$ Seasonal Stall Feeding adoption

Considering the case of full adoption (FSF), households that adopted SF would have harvested 0.39 ( 21.7 per cent) litres/cow less in the case of FSF and 2 litres/cow in the case of SSF had they not adopted; their lactation period would have declined by 0.29 (3.5 per cent) months respectively. Had nonparticipants chosen to adopt, they would have increased their milk harvest by 2.3 litres per cow and their lactation period would have increased by 1 months. The result that SF positively influences milk production and lactation is a confirmation that SF contributes to boost productivity. The additional average gain for adopters at household level due to SSF adoption is about 11827 ETB per average lactation period (1.76*2 cows*14 ETB*240days) where 2 is the average milking cow, 14 is the price of milk per litre milk and 240 days is an average lactating period in the study area. This is consistent with the idea that adoption of new agricultural technology can improve household welfare (Wambugu et al., 2011; Shiferaw et al., 2014; Khonje et al., 2015; Hadush \& Hagos, 2018). 
We also observe a positive and significant impact of SF on households' milk and milk product consumption expenditure. The same Table shows that farmers who adopt FSF and SSF would have spent about 268 ETB and 553 ETB less on meat and milk products if they had not adopted. The ATU estimates show that farm households who did not adopt would have spent about 1228 ETB more on meat and milk products if they had adopted. Our results are similar to previous studies that have used different estimation methods and have found a positive effect of stall feeding on the use of inputs (Wambugu et $a l ., 2011$ ) in Kenya and (Turinawe et al., 2011) in Uganda.

Consistent with our expectation, the results further show that adoption of SF significantly increased the probability of selling animal and animal product by 29 per cent for adopters. For non-adopters, the ATU estimates show that the probability of market participating would have been 47 per cent higher had they adopted the technology. A similar result was obtained by Wambugu et al., (2011) in Kenya and Turinawe et al., (2011) in Uganda who found a higher volume of animal and product sale in SF users.

Regarding land conservation, Table 6 demonstrates the significant and positive impact of ATT, implying that adopters of SF in full year would increase their land conservation by 29 -metre construction of stone bunds and soil bunds on their plots. Similarly, The ATU value of 134 metres of stone and sopil bund construction signifies that non-adopters would increase land conservation if FSF was adopted by non- adopters for cattle farming. The result also shows that the mean value of planted trees of SF adoption is statistically higher than had they not been adopted. SF adoption increases tree plantation by about 11 trees on a given plot. For non-adopters, the mean planted tree would have been increased by 36.5 trees had they adopted FSF. This is consistent with the result from Nyssen et al., (2007) and Garcia et al., (2008) whose result found that the practice of SF was ecologically sustainable. The adoption process also increased the propensity of growing trees by 19 per cent and 12 per cent for adopter and non-adopters. In summary, non-adopters would improve land conservation from being adopters than remaining as nonadopters, indicating that the decision to adopt SF seems to be rational.

\section{Summary and Conclusion}

In this paper, efforts were made to assess the impact of adoption of full (FSF) and seasonal (SSF) stall feeding technology on households' milk production and consumption, market participation and land conservation in rural Northern Ethiopia using data of 518 rural farmers collected in 2015 by applying endogenous switching regression model. First, existences of initial differences in explanatory and outcome variables among households were examined using descriptive statistics. The overall result indicated that SF adoption ensures mixed benefits in response to differences in factor endowments, household characteristics, farm attributes and location factors, which create differences in marginal benefit, and the resulting differences in marginal benefit induce farm households to adopt SF. 
We found that the SF adoption is positively influenced by animal feed value, zonal variation, gender, family size, off-farm income, access to information and fodder shed, forage expense, breed cow possession, animal shock, distance to grazing land and early SF exposure, but negatively associated with total land and herd size, geographic location, distance to road. The result also indicates that adoption of improved cow, availability of grazing land, family and hired labour, agro-ecology variation, access to animal and fodder shed determine the amount of milk production. With regard to milk and milk product consumption expenditure, the findings have revealed that household total food expenditure, herd size and gender has been proven to increase consumption expenditure. In examining factors affecting animal market participation for sales, the results show that ownership of cattle, population density, family size, agro-ecology variation, distance to market and animal shock experience are the main factors influencing market participation in animal sales.

Using ESR models, we estimate different outcome indicators for both adopters from adoption (ATT), and non-adopters had they adopted (ATU). The adoption of FSF and SSF leads to significant gains in milk production and consumption expenditure, lactation period, and animal market participation. It is identified that there would be a decline of 21 per cent in milk production if adopters would not have adopted this technology. On the other hand, nonadopters could increase their milk production and productivity by 100 per cent and 48 per cent if they would adopt this technology. The results further show that $\mathrm{SF}$ adoption had significant effects on lactation period, increasing positive impacts for adopters and non-adopters if they were to adopt the technology.

An increase of consumption expenditure by 17 per cent from FSF and 44 per cent in the case of SSF could be considered significant on livelihoods for smallholder farmers in Tigrai and such a positive impact should not be ignored. Among adopters, the adoption of SF increased the likelihood of participating in an animal sale market by 29 per cent while non-adopters would have increased their participation by 47 per cent had they decided to adopt. Along with the positive biophysical and environmental benefits of the adoption of SF, which are well documented in the literature, the adoption of SF leads to a gain in a number of plants of 11 trees and 29 metres of physical construction for the typical adopter and 36 trees and 133 metres if the typical non-adopter were to adopt the SF technology. The adoption process also increased the propensity of growing trees by 19 per cent and 12 per cent for adopters and non-adopters respectively.

These findings demonstrate the importance of SF technology for enhancing cattle performance (milk production and consumption, lactation), market participation (animal live and animal product), and land investment (plantation and soil construction) of smallholder farmers in semi-arid areas. This paper highlights the important nexus between household's decision on livestock production, land investment and technology introduction and 
adoption. Local and regional policies that can enable local farmers to respond to land degradation and livestock shocks should promote and support full scale SF adoption. Therefore, wider adoption of SF has great potential for transforming the agricultural sector in general and the welfare of small rural farmers in the region. The policy implication of our results is that the national government should consider embracing SF as one of the priority farming packages in its national extension agenda and develop policies which overcome limitations for wider expansion. Policies that promote livestock production and soil conservation should promote full year SF adoption and expansion.

\section{References}

Adane, Z., K. Shiferaw, and B. Gebremedhin (2015). Sources of Technical Inefficiency of Smallholder Farmers in Milk Production in Ethiopia. LIVES Working Paper 3. Nairobi, Kenya: ILRI.

Aidoo, R., G.K. Nurah, S.C. Fialor and K. Ohene-Yankyera, K. (2009). Determinants of Dairy Consumption Expenditure in Urban Communities of Southern Ghana. Journal of Science and Technology, 29(1), 87-96.

Alamirew, B. (2011). The Impact of Poverty, Tenure Security and Risk on Sustainable Land Management Strategies in North Central Ethiopia: Analysis Across Three Agro-ecological Zones. Journal of Sustainable Development Africa, 13, 227-240.

Alene, A.D. and V.M. Manyong (2007). The Effects of Education on Agricultural Productivity Under Traditional and Improved Technology in Northern Nigeria: An Endogenous Switching Regression Analysis. Empirical Economics, 32(1), 141-159.

Ayenew, H.Y., J. Sauer and G. Abate-Kassa (2015) Exposure to Risk and Risk Management in Smallholder Agriculture. In 55th Annual Conference, Giessen, Germany, (No. 209211). German Association of Agricultural Economists.

Baltenweck, I., J.S. Tenywa and J. Mugisha (2007). Dairy Farming in Uganda: Production Efficiency and Soil Nutrients under Different Farming Systems. Vol. 1. ILRI (aka ILCA and ILRAD), Nairobi, Kenya.

Behnke, R.H. and F. Metaferia (2011). The Contribution of Livestock to the Ethiopian Economy. Part II.IGAD Livestock Policy Initiative, IGAD LPI Working Paper No. 02-11. Djibouti: IGAD.

Blundell, R. and M. Costa Dias (2000). Evaluation Methods for Nonexperimental Data. Fiscal Studies, 21(4), 427-468. 
Benin, S., S. Ehui and J. Pender (2006). Policies for Livestock Development in the Ethiopian Highlands. Chapter 6 in International Food Policy Research Institute (ed), Strategies for Sustainable Land Management in the East African Highlands, Nairobi. IFPRI, 141-165.

Bishu, K.G. (2014). Risk Management and the Potential of Cattle Insurance in Tigray, Northern Ethiopia. Ph.D. Thesis, University College Cork.

Cary, J., T. Webb and N. Barr (2001). The Adoption of Sustainable Practices: Some New Insights. An Analysis of Drivers and Constraints for the Adoption of Sustainable Practices Derived from Research. Bureau of Rural Sciences, Canberra.

CSA (Central Statistics Authority). (2008). Central Statistics Authority of the Federal Democratic. The Republic of Ethiopia. Agricultural sample survey 2007/2008. Vol. II. Report on livestock and livestock characteristics. Statistical bulletin. Addis Ababa, Ethiopia: CSA.

Ehui, S., S. Benin and Z. Paulos (2003). Policy Options for Improving Market Participation and Sales of Smallholder Livestock Producers: A Case Study of Ethiopia. International Conference on African Development Archives.

De Cao, E., M.M. van den Berg, C.Y. Tile and T. Wondwosen (2013). The Effects of Zero Grazing in Ethiopia. In Proceedings of the CSAE Conference 2013: Economic Development in Africa, 1-15.

Di Falco, S. and M. Veronesi (2013). How can African Agriculture Adapt to Climate change? A Counterfactual Analysis from Ethiopia. Land Economics, 89(4), 743-766.

D'Emden, F.H., R.S. Llewellyn and M.P. Burton (2006). Adoption of Conservation Tillage in Australian Cropping Regions: An Application of Duration Analysis. Technological Forecasting and Social Change, 73(6), 630-647.

Diao, X. and A.N. Pratt (2007). Growth Options and Poverty Reduction in Ethiopia-An Economy-wide Model Analysis. Food Policy, 32(2), 205-228.

del Corral, J., J.A. Perez and D. Roibás (2011). The Impact of Land Fragmentation on Milk Production. Journal of Dairy Science, 94(1), 517-525.

Ewnetu, Z. J.C. Bliss (2010). Tree Growing by Small Holder Farmers in the Ethiopian Highlands. In Small Scale Forestry in Changing World: Opportunities and Challenges and the Role of Extension and Technology Transfer. IUFRO Conference, 3. 
FAO (Food and Agriculture Organization of the United Nations) (2005). Production Yearbook. FAO, Rome, Italy.

FAO. (Food and Agriculture Organization of the United Nations) (2007). TerrAfrica- A Vision paper for Sustainable Land Management in Sub-Saharan Africa. Food and Agriculture Organization of the United Nations, Rome, Italy.

FAO (Food and Agriculture Organization of the United Nations) (2009). Production Yearbook, FAO, Rome, Italy. http://faostat.fao.org/default.aspx.

Fernandez-Cornejo, J., C. Hendricks and A. Mishra (2005). Technology Adoption and Off-farm Household Income: The Case of HerbicideTolerant Soybeans. Journal of Agricultural and Applied Economics, 37(3), 549-563.

Frankl, A., J. Deckers, L. Moulaert, A. Van Damme, M. Haile, J. Poesen and J. Nyssen (2016). Integrated Solutions for Combating Gully Erosion in Areas Prone to Soil Piping: Innovations from the Drylands of Northern Ethiopia. Land Degradation \& Development, 27(8), 1797 1804.

Garcia, O., D. Balikowa, D. Kiconco, A. Ndambi and T. Hemme (2008). Milk Production in Uganda. Dairy Farming Economics and Development Policy Impacts. IGAD LPI, Working Paper No. 09 08 .

Gebregziabher, G. and H. Gebrehiwot (2011). Challenges, Opportunities and Available Good Practices related to Zero Grazing in Tigray and Hararghe, Ethiopia. DCG Report No. 66.

Gebremedhin, B., J. Pender and G. Tesfay (2004). Collective Action for Grazing Land Management in Crop-livestock Mixed Systems in the Highlands of Northern Ethiopia. Agricultural Systems, 82(3), 273 290.

Gebremedhin, B., Hirpa, A., and Berhe, K. (2009). Feed Marketing in Ethiopia: Results of Rapid Market Appraisal. Improving Productivity and Marketing Success (IPMS) of Ethiopian Farmers Project Working Paper, 15. ILRI, Nairobi.

Ghadim, A.K.A., D.J. Pannell and M.P. Burton (2005). Risk, Uncertainty, and Learning in Adoption of a Crop Innovation. Agricultural Economics, 33(1), 1-9. 
Grassi, J., J. Lamberg and S. Huyer, S. (2015). Running out of Time: The Reduction of Women's Work Burden in Agricultural Production. Food and Agriculture Organization of the United Nations. Rome, Italy.

Gessesse, B., W. Bewket and A. Bräuning (2016). Determinants of Farmers' Tree-planting Investment Decisions as a Degraded Landscape Management Strategy in the Central Highlands of Ethiopia. Solid Earth, 7(2), 639-650.

Gunte, K.E. (2015). Understanding Factors Affecting Technology Adoption in Smallholder Livestock Production Systems in Ethiopia: The Role of Farm Resources and the Enabling Environment. Doctoral Dissertation, Wageningen: Wageningen University.

Hadush, M. (2018). Understanding Farmers Seasonal And Full Year Stall Feeding Adoption In Northern Ethiopia. Review of Agricultural and Applied Economics, 21(1), 23-39.

Hadush M and B.G. Hagos (2018). The Economic Impact of Stall Feeding on Cow Milk Production and Calf Death: Empirical Evidence from Northern Ethiopia. Asian Journal of Agriculture and Rural Development, 8(1), 64-73.

Halderman, M.N. (2004). The Political Economy of Pro-poor Livestock Policy Making in Ethiopia. FAO Working Paper No. 19. Rome: FAO.

Hausman, J.A. (1978). Specification Tests in Econometrics. Econometrica, 46, 1251-1272.

Heckman, J. (1979). Sample Selection as a Specification Error. Econometrica, 47, 153-161.

Heckman, J.J. (2001). Econometrics and Empirical Economics. Journal of Econometrics, 100(1), 3-5.

Herrero, M., D. Grace, J. Njuki, N. Johnson, D. Enahoro, S. Silvestri and M.C. Rufino (2013). The Roles of Livestock in Developing Countries. Animal, 7(1), 3-18.

Holden, S.T. and N.B. Westberg (2016). Exploring Technology Uses under Climate Risk and Shocks through an Experimental Lens. African Journal of Agricultural and Resource Economics, 11(1), 47-62. 
Holtland, G. (2007). Eroded Consensus: However-changing Policy Narratives Distort the Interpretation of Livelihood Systems: The Uneasy Relationship between Science and Development: A Case Study from Central Tanzania. The Netherlands: NUFFIC and CIDIN Radboud University.

Huffman, W.E. (1991). Agricultural Household Models: Survey and Critique. Multiple Job-holding among Farm Families. Hallberg M.C., Findeis J.L., and Lass D.A., eds. Ames: Iowa State University Press.

IFAD. (2007). Livestock and Range Lands; Livestock Feeding. Retrieve from http://www.ifad.org/lrkm/theme/production/feeding.htm.

Ilyin, S. (2011). The Looming Threat of Overgrazing: Effects and Recommendations. Congressional Hunger Center. [Online] http://Hungercenter.wpengine.netdna-cdn.com / wp-content Looming-Threat-of-Overgrazing-Ilyin.pdf (uploaded 09, 2011).

Kabirizi, J.M.L. (2006). Effect of Integrating Forage Legumes in Smallholder Dairy Farming Systems on Feed Availability and Animal Performance. Unpublished Ph.D thesis, Makerere University, Uganda.

Khonje, M., J. Manda, A.D. Alene and M. Kassie (2015). Analysis of Adoption and Impacts of Improved Maize Varieties in Eastern Zambia. World Development, 66, 695-706.

Klitzing, A., A. Das, M. Bonzi, A. Barro, U. Langkamp, K. Dereje, S. Pale, S. Nayak and A. Gupta (2014). Promoting Best Practice in Agriculture: Examples from Burkina Faso, Ethiopia, India and Europe. Deutsche Welthungerhilfe e.V., Friedrich-Ebert-Straße 1, 53173 Bonn.

Kuma, B., D. Baker, K. Getnet and B. Kassa (2014). Factors Affecting Market Participation and Volume of Supply in Ethiopia. Asian Journal of Rural Development, 4(1), 1-15.

Lenaerts, L. (2013). Insights into Agency and Social Interactions in Natural Resource Management. Ph.D. Thesis, Wageningen University.

Lokshin, M. and Z. Sajaia (2004). Maximum Likelihood Estimation of Endogenous Switching Regression Models. Stata Journal, 4, 282289.

MoA (Ministry of Agriculture). (2012). Livestock Growth Strategy and Action. Draft Discussion Paper. Addis Ababa: MoA. (Amharic version). 
Meul, M., S. Van Passel, D. Fremaut and G. Haesaert (2012). Higher Sustainability Performance of Intensive Grazing versus Zero-grazing Dairy Systems. Agronomy for Sustainable Development, 32(3), 629638.

Makoni, N., R. Mwai, T. Redda, A.J. van der Zijpp and J. van der Lee (2014). White Gold: Opportunities for Dairy Sector Development Collaboration in East Africa. Centre for Development Innovation, Wageningen UR.

Nalunkuuma, J., H. Affognon, S.W. Kingori, D. Salifu and F.K. Njonge (2013). Adoption of Zero Grazing and Impact on Livestock Keepers' Knowledge of Cattle Reproductive Parameters in Western Kenya. African Crop Science Conference Proceedings, 11, 599-604.

Nedessa, B., J. Ali and I. Nyborg (2005). Exploring Ecological and Socioeconomic Issues for the Improvement of Area Enclosure Management: A Case Study from Ethiopia. Drylands Coordination Group, DCG Report No. 38.

Negassa, A. and M. Jabbar (2008). Livestock Ownership, Commercial Offtake Rates and Their Determinants in Ethiopia. Research Report 9. Nairobi, Kenya: ILRI.

Nyssen, J., K. Descheemaeker, M.H. Nigussie Haregeweyn, J. Deckers and J. Poesen (2007). Lessons Learned from 10 Years Research on Soil Erosion and Soil and Water Conservation in Tigray. Tigray Livelihood Papers No.7, Mekelle.

Odame, H., L. Kimenye, C. Kabutha, D. Alemu and L.H. Oduori (2013). Why the Low Adoption of Agricultural Technologies in Eastern and Central Africa? ASARECA (Association for Strengthening Agricultural Research in Eastern and Central Africa), Entebbe.

Oni, O. A. Fashogbon (2012). Rural Household Consumption of Milk and Products in Nigeria. Journal of Agricultural and Biological Science, 7(12), 1062-1069.

Shiferaw, B., M. Kassie, M. Jaleta C. Yirga (2014). Adoption of Improved Wheat Varieties and Impacts on Household Food Security in Ethiopia. Food Policy, 44, 272-284.

Singh, I., L. Squire and J. Strauss (1986). Agricultural Household Models. Extension, Applications, and Policy. The Johns Hopkins University Press Baltimore, Maryland 21211, USA. 
Sserunkuuma, D. (2005). The Adoption and Impact of Improved Maize and Land Management Technologies in Uganda. Journal of Agricultural and Development Economics, 2(1), 67- 84.

Staal, S.J., M. Waithaka, L. Njoroge, D.M. Mwangi, D. Njubi and A. Wokabi (2003). Costs of Milk Production in Kenya: Estimates from Kiambu, Nakuru and Nyandarua districts. SDP Research and Development, Report No.1 Smallholder Dairy Project.

Tegegne, A., B. Gebremedhin, D. Hoekstra, B. Belay and Y. Mekasha (2013). Smallholder Dairy Production and Marketing Systems in Ethiopia: IPMS Experiences and Opportunities for Market-oriented Development. IPMS Working Paper 31. ILRI, Nairobi, Kenya.

Teshome, A., J. Graaff, C. Ritsema and M. Kassie (2016). Farmers' Perceptions about the Influence of Land Quality, Land Fragmentation and Tenure Systems on Sustainable Land Management in the North Western Ethiopian Highlands. Land Degradation \& Development 27(4), 884-898.

Turinawe, A., J. Mugisha and J. Kabirizibi (2011). Socio-economic Evaluation of Improved Forage Technologies in Smallholder Dairy Cattle Farming Systems in Uganda. Journal of Agricultural Science, 4(3), 163.

Wambugu, S., L. Kirimi and J. Opiyo (2011). Productivity Trends and Performance of Dairy Farming in Kenya. Tegemeo Institute of Agricultural Policy and Development.

World Bank. (2008). World Development Report. Agriculture for Development. The World Bank, Washington, DC.

Yilma, Z., E. Guernebleich, A. Sebsibe and R. Fombad (2011). A Review of the Ethiopian Dairy Sector. Addis Ababa, Ethiopia: FAO Sub Regional Office for Eastern Africa. 